\title{
A New Fluorescent Chemosensor for Cobalt(II) Ions in Living Cells Based on 1,8-Naphthalimide
}

\author{
Yu-Long Liu ${ }^{1,+} \mathbb{C}$, Liu Yang ${ }^{1,+}{ }^{,}$Lu Li ${ }^{1}$, You-Quan Guo ${ }^{2}$, Xiao-Xiao Pang ${ }^{1}$, Ping Li ${ }^{1}$, Fei Ye ${ }^{1}$ and \\ Ying Fu ${ }^{1, * \mathbb{D}}$ \\ 1 Department of Applied Chemistry, College of Science, Northeast Agricultural University, \\ Harbin 150030, China \\ 2 Heilongjiang Vocational College of Biology Science and Technology, Harbin 150025, China \\ * Correspondence: fuying@neau.edu.cn; Tel.: +86-451-5519-0070 \\ + These authors contributed equally to this work.
}

Received: 6 August 2019; Accepted: 26 August 2019; Published: 26 August 2019

\begin{abstract}
In this work, a highly selective fluorescent chemosensor N-(2-(2-butyl-1,3-dioxo-2,3dihydro-1H-benzo[de] isoquinolin-6-yl)hydrazine-1-carbonothioyl)benzamide (L) was prepared and characterized. An assay to detect the presence of cobalt(II) ions was developed by utilizing turn-on fluorescence enhancement with visual colorimetric response. Upon treatment with $\mathrm{Co}^{2+}$, a remarkable fluorescence enhancement located at $450 \mathrm{~nm}$ was visible to naked eyes accompanied with a distinct color change (from pink to colorless) in a $\mathrm{CH}_{3} \mathrm{CN} / \mathrm{HEPES}(4 / 1, v / v, \mathrm{pH}=7.4)$ solution due to the formation of a 1:1 complex at room temperature. In addition, the linear concentration range for $\mathrm{Co}^{2+}$ was $0-25 \mu \mathrm{M}$ with the limit of detection down to $0.26 \mu \mathrm{M}$. Thus, a highly sensitive fluorescent method based on chelation-assisted fluorescence enhancement was developed for the trace-level detection of $\mathrm{Co}^{2+}$. The sensor was found to be highly selective toward $\mathrm{Co}^{2+}$ ions with a large number of coexisting ions. Furthermore, the $\mathbf{L}$ probe can serve as a fluorescent sensor for $\mathrm{Co}^{2+}$ detecting in biological environments, demonstrating its low toxic properties to organisms and good cell permeability in live cell imaging.
\end{abstract}

Keywords: 1,8-naphthalimide; colorimetric; fluorescent; cobalt(II) ions; live cell imaging

\section{Introduction}

Cobalt is a transition metal element present in rocks, soil, plants and animals in trace levels and is widely used in various materials such as alloys [1], batteries [2] and catalysts [3]. As a vital trace element in human body, cobalt plays vital roles in various physiological processes which are essential to the metabolism of all animals [4,5]. Meanwhile, cobalt is a key constituent of cobalamin, also known as vitamin B12, whose insufficiency ultimately gives rise to hematological and neurological disorders [6]. Therefore, cobalt, a trace element in nature, is beneficial to organisms. However, the excessive intake of $\mathrm{Co}^{2+}$ by the body can cause toxicological effects including asthma, rhinitis, allergic dermatitis vasodilation and cardiomyopathy in human and animals [7,8]. Furthermore, in view of the toxic effect caused by $\mathrm{Co}^{2+}$, it is a significant environmental pollutant, and the maximum acceptable level of $\mathrm{Co}^{2+}$ in drinking water is permitted to be $40 \mu \mathrm{g} \cdot \mathrm{L}^{-1}$ (World Health Organization) [9]. Hence, a highly selective and sensitive determination of trace amounts of $\mathrm{Co}^{2+}$ is essential and of great importance in biological and environmental samples.

Several principal analytical methods including inductively coupled plasma atomic emission spectrometry (ICP-AES) [10], flame atomic absorption spectrometry [11], surface plasmon resonance (SPR) [12], surface-enhanced Raman scattering (SERS) [13], chemiluminescence [14] and electrochemical methods [15] have been reported aiming to detect $\mathrm{Co}^{2+}$. Unfortunately, these techniques usually require 
either expensive equipment, cumbersome processes, or tedious pretreatments, making them difficult to apply to the real-time determination of $\mathrm{Co}^{2+}$. Due to the limitations of these methods, the development of chemosensors towards $\mathrm{Co}^{2+}$ ions with high sensitivity and easy operation is still a significant work for researchers. Colorimetric methods for $\mathrm{Co}^{2+}$ detection which can conveniently and easily monitor target ions with the naked eye have attracted considerable attention [16-25]. Additionally, a fluorescence probe has also evolved to be a promising candidate for detecting $\mathrm{Co}^{2+}$ by virtue of its high specificity towards target substances, great simplicity and high-speed analysis during the process of experiments [26-29]. These chemosensors, however, are based on two independent kinds of response mechanism - colorimetric detection and fluorometric detection. Due to their highly sensitive and selective sensing for target ions with the naked eye, it would be beneficial if the colorimetric and fluorescent methods could be joined together with inexpensive equipment which is convenient and easy to operate. On the other hand, some of these probes suffer from notable toxicity, low bio-compatibility, and complicated synthetic processes, which may hinder their specific application in related fields. Consequently, for the further and efficient detection of $\mathrm{Co}^{2+}$, searching for a novel and concise probe is still in urgent demand.

Fluorophore naphthalimide is widely used for the construction of excellent fluorescent chemosensors because of its excellent photophysical properties such as remarkable chemical stability, large Stokes shift, high fluorescent quantum yields and ease of structural modification [30-37]. Thiourea is generally utilized as a receptor unit for the molecular design of probe for metal ions such as $\mathrm{Ag}^{+}$, $\mathrm{Hg}^{2+}, \mathrm{Zn}^{2+}, \mathrm{Pb}^{2+}, \mathrm{Fe}^{3+}$ and $\mathrm{F}^{-}$due to its strong chelation with transition metal ions (Scheme 1) [37-40]. It is expected that the combination of naphthalimide and thiourea units will create a novel type of probe which may be utilized for the detection of transition metal ions. In this paper, we explored the possibility of this combination mode and attached thiourea together with carbonyl to 1,8-naphthalimide through an imino group.

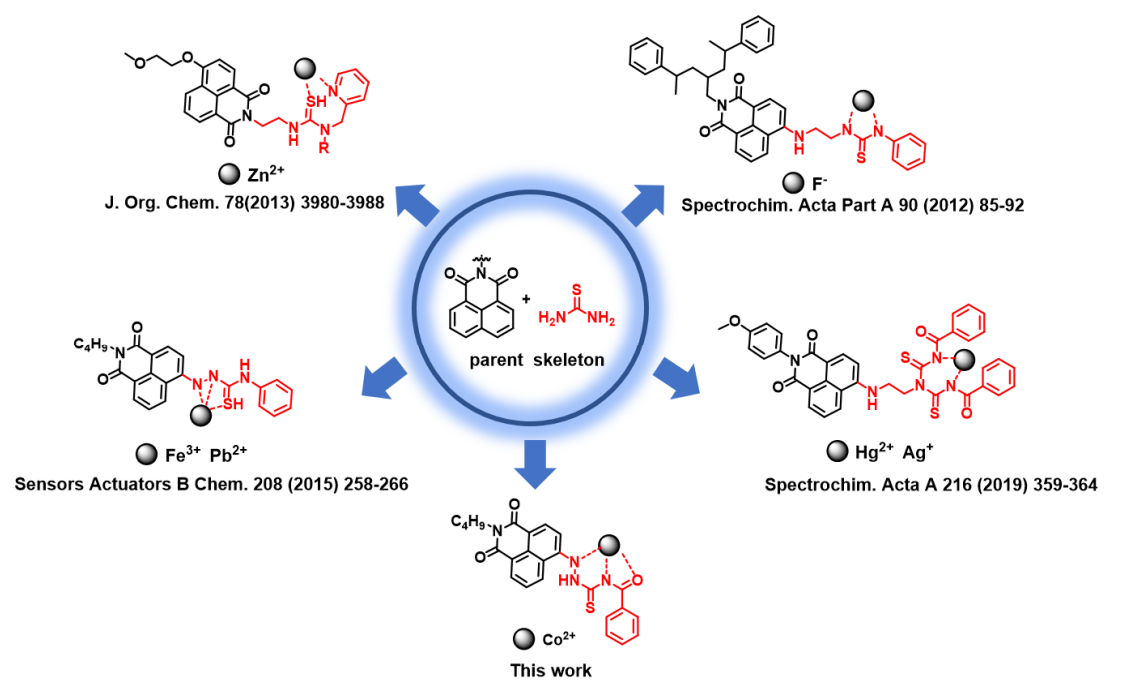

Scheme 1. Design of the chemosensors based on thiourea-appended 1,8-naphthalimide.

Based on this consideration, a new chemosensor $N$-(2-(2-butyl-1,3-dioxo-2,3-dihydro- $1 H$ benzo[de]isoquinolin-6-yl)hydrazine-1-carbonothioyl)benzamide (L) was designed and synthesized for the highly selective detection of $\mathrm{Co}^{2+}$. The $\mathbf{L}$ chemosensor detected $\mathrm{Co}^{2+}$ by a color change from pink to colorless via the naked eye with high selectivity. In addition, ${\mathrm{L}-\mathrm{Co}^{2+}}^{2+}$ showed a remarkable enhancement of the fluorescence intensity in a $\mathrm{CH}_{3} \mathrm{CN} / \mathrm{HEPES}(4 / 1, v / v, \mathrm{pH}=7.4)$ solution. Moreover, the $\mathbf{L}$ probe could detect $\mathrm{Co}^{2+}$ down to a concentration of $0.26 \mu \mathrm{M}$. The qualitative and quantitative analysis of $\mathrm{Co}^{2+}$ ions can be realized through color transformation and spectral changes, respectively. It was envisioned that the free $\mathbf{L}$ emitted weak fluorescence due to the photoinduced electron transfer (PET) and intramolecular charge transfer (ICT) processs from the imino $\mathrm{N}$ atom to the naphthalimide units. 
However, the coordination of $\mathrm{Co}^{2+}$ with ligating atoms modulated the electron/charge distribution not only blocked the PET effect, it also reduced the low-energy ICT emission. Last but not the least, the $\mathbf{L}$ probe was workable and effective for the fluorescence imaging of $\mathrm{Co}^{2+}$ in a biological environment.

\section{Results and Discussion}

\subsection{UV-Vis and Fluorescence Response of the L Probe Toward Various Metal Ions}

The colorimetric selectivity of the $\mathbf{L}$ sensor was examined first. The absorption response of $\mathbf{L}$ with various metal ions of $\mathrm{Na}^{+}, \mathrm{K}^{+}, \mathrm{Ag}^{+}, \mathrm{Cu}^{+}, \mathrm{Mg}^{2+}, \mathrm{Zn}^{2+}, \mathrm{Ca}^{2+}, \mathrm{Sn}^{2+}, \mathrm{Cu}^{2+}, \mathrm{Ni}^{2+}, \mathrm{Mn}^{2+}, \mathrm{Pb}^{2+}$, $\mathrm{Cd}^{2+}, \mathrm{Ba}^{2+}, \mathrm{Hg}^{2+}, \mathrm{Fe}^{2+}, \mathrm{Co}^{2+}, \mathrm{Fe}^{3+}, \mathrm{Al}^{3+}$ and $\mathrm{Cr}^{3+}$ was carried out in $\mathrm{CH}_{3} \mathrm{CN} / \mathrm{HEPES}(4 / 1, v / v, \mathrm{pH}$ = 7.4). As shown in Figure $1, \mathrm{~L}\left(1 \times 10^{-5} \mathrm{M}\right)$ itself in $\mathrm{CH}_{3} \mathrm{CN} / \mathrm{HEPES}(4 / 1, v / v, \mathrm{pH}=7.4)$ showed a pink color and an obvious absorption peak emerged at $510 \mathrm{~nm}$, which may be due to the existence of intramolecular charge transfer (ICT) transition between the nitrogen atom (often an amide group) and the quinone ring [41], which thus caused absorption in the visible region. Upon the addition of five equivalents of $\mathrm{Co}^{2+}$, the band at $510 \mathrm{~nm}$ decreased sharply, almost disappeared and was accompanied by a weak absorbance under 0.05 , which means nearly no absorption was observed in the visible region $(420-700 \mathrm{~nm})$. This was because of the coordination of the nitrogen atom and $\mathrm{Co}^{2+}$, which resulted in the extremely decreased electron-donating ability of the nitrogen atom involved in coordination; accordingly, this decreased ICT transition. Meanwhile, the absorption band at a short wavelength area (300-420 nm) was redshifted by about $20-50 \mathrm{~nm}$ relative to that of $\mathbf{L}$ and $\mathbf{L}$ with other cations. This was probably caused by the complexation of $\mathrm{Co}^{2+}$, with $\mathbf{L}$ giving an increased degree of conjugate for the ${\mathrm{L}-\mathrm{Co}^{2+}}^{2+}$ complex. The addition of $\mathrm{Co}^{2+}$ caused obvious absorbance changes, not only in the UV range but also in the visible range. Through reacting with $\mathrm{Co}^{2+}, \mathrm{L}$ exhibited a weak absorption with a color change from pink to colorless which could be easily read out with the naked eye. Other cations had negligible effects on the absorption peak.

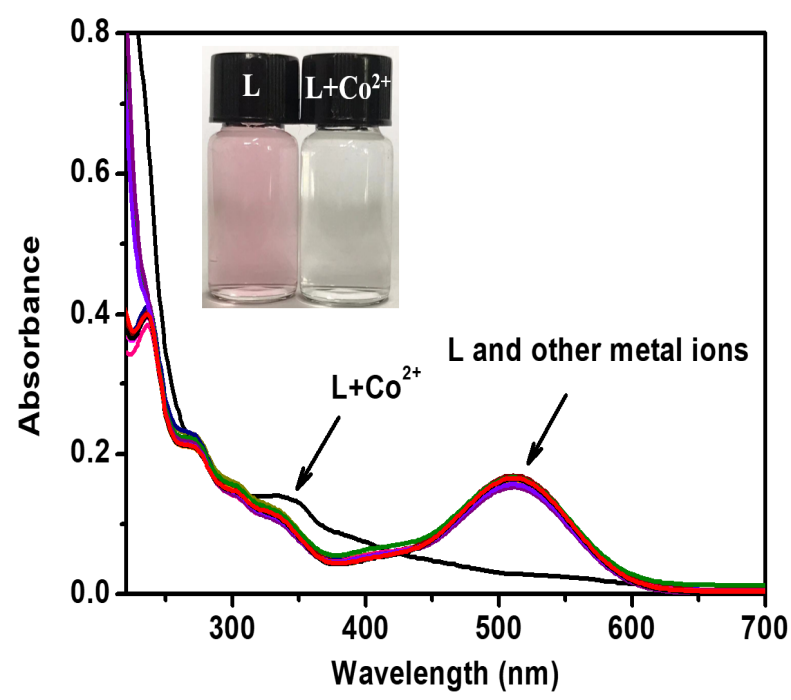

Figure 1. UV-Vis absorption spectra of $\mathbf{L}\left(1 \times 10^{-5} \mathrm{~mol} \mathrm{~L}^{-1}\right)$ and upon the addition of salts (five equivalents) of $\mathrm{Na}^{+}, \mathrm{K}^{+}, \mathrm{Ag}^{+}, \mathrm{Cu}^{+}, \mathrm{Mg}^{2+}, \mathrm{Zn}^{2+}, \mathrm{Ca}^{2+}, \mathrm{Sn}^{2+}, \mathrm{Cu}^{2+}, \mathrm{Ni}^{2+}, \mathrm{Mn}^{2+}, \mathrm{Pb}^{2+}, \mathrm{Cd}^{2+}, \mathrm{Ba}^{2+}$, $\mathrm{Hg}^{2+}, \mathrm{Fe}^{2+}, \mathrm{Co}^{2+}, \mathrm{Fe}^{3+}, \mathrm{Al}^{3+}$ and $\mathrm{Cr}^{3+}$ in a $\mathrm{CH}_{3} \mathrm{CN} / \mathrm{HEPES}(4 / 1, v / v, \mathrm{pH}=7.4)$ solution. Inset: Visual colorimetric response of $\mathbf{L}$ with $\mathrm{Co}^{2+}$.

To obtain insight into the fluorescent properties of $\mathbf{L}$ towards metal ions, these ions' fluorescence spectra in a $\mathrm{CH}_{3} \mathrm{CN} / \mathrm{HEPES}(4 / 1, v / v, \mathrm{pH}=7.4)$ solution were investigated. As displayed in Figure 2, $\mathbf{L}\left(1 \times 10^{-5} \mathrm{M}\right)$ alone had a weak fluorescence emission with broadened photoluminescence, which is consistent with the fluorescence property of intramolecular charge transfer transition [42]. When five equivalents of metal ions such as $\mathrm{Na}^{+}, \mathrm{K}^{+}, \mathrm{Ag}^{+}, \mathrm{Cu}^{+}, \mathrm{Mg}^{2+}, \mathrm{Zn}^{2+}, \mathrm{Ca}^{2+}, \mathrm{Sn}^{2+}, \mathrm{Cu}^{2+}, \mathrm{Ni}^{2+}, \mathrm{Mn}^{2+}$, 
$\mathrm{Pb}^{2+}, \mathrm{Cd}^{2+}, \mathrm{Ba}^{2+}, \mathrm{Hg}^{2+}, \mathrm{Fe}^{2+}, \mathrm{Fe}^{3+}, \mathrm{Al}^{3+}$ and $\mathrm{Cr}^{3+}$ was added to the $\mathrm{L}$ sensor, it was found that the solution of $\mathbf{L}$ either exhibited no or a small significant increase in fluorescence. By contrast, a 33-fold enhancement of the fluorescence intensity was presented upon the addition of five equivalents of $\mathrm{Co}^{2+}$ with a slight blue-shift of fluorescence spectra caused by the suppression of the charge transfer state (Figure 2). The quantum yields of the $\mathbf{L}$ probe with and without five equivalents of $\mathrm{Co}^{2+}$ were 0.63 and 0.02 , respectively. when rhodamine B was selected as the standard $\left(\Phi_{\mathrm{F}}=0.69\right.$ in $\left.\mathrm{CH}_{3} \mathrm{CN}\right)$. Importantly, only $\mathrm{Co}^{2+}$ strengthened the fluorescence. The $\mathbf{L}$ probe nearly emitted no fluorescence in solution ("off" state) as the dark-state of PET and ICT process with inferior radiative transition from the electron-rich amide moiety to the naphthalimide fluorophore occurred [43]. Upon the addition of $\mathrm{Co}^{2+}$, the coordination between $\mathrm{Co}^{2+}$ and the receptor unit of $\mathrm{L}$ restrained the PET and ICT processes, directly leading to a strong local-state emission presenting at blue band ("on" state), which is very sensitive to naked eyes (Figures 2 and 3). On the other hand, the low fluorescence of $\mathbf{L}$ may be due to its flexibility, which contributed to the nonradiative decay in the excited state dynamics. The free rotation of receptor and spacer of the $\mathbf{L}$ sensor in the presence of $\mathrm{Co}^{2+}$ restricted intramolecular motions (RIM) [44], and the cobalt complex became a more rigid, coplanar configuration than the $\mathrm{L}$ itself, resulting in a chelation enhanced fluorescence (CHEF) effect [45,46] (vide infra, Figure 7). Thus, $\mathbf{L}$ showed a significant increase of the fluorescence intensity and a distinct color change due to the suppression of PET and ICT processes from the ligand to the chromophore core of naphthalimide, which indicates that the $\mathbf{L}$ sensor could be used as an efficient fluorescence chemosensor for $\mathrm{Co}^{2+}$. These results revealed that $\mathbf{L}$ compound exhibited the ability to selectively discriminate $\mathrm{Co}^{2+}$ from other cations.

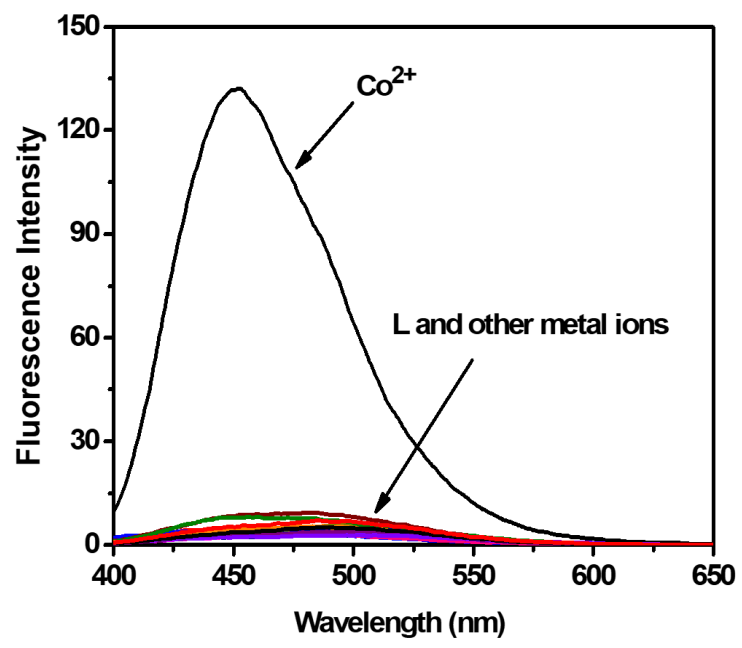

Figure 2. Fluorescence spectra $\left(\lambda_{\mathrm{ex}}=380 \mathrm{~nm}\right)$ of the $\mathbf{L}$ sensor $\left(1 \times 10^{-5} \mathrm{~mol} \mathrm{~L}^{-1}\right)$ before and in the presence of five equivalents of various metal ions $\left(\mathrm{Na}^{+}, \mathrm{K}^{+}, \mathrm{Ag}^{+}, \mathrm{Cu}^{+}, \mathrm{Mg}^{2+}, \mathrm{Zn}^{2+}, \mathrm{Ca}^{2+}, \mathrm{Sn}^{2+}, \mathrm{Cu}^{2+}\right.$, $\mathrm{Ni}^{2+}, \mathrm{Mn}^{2+}, \mathrm{Pb}^{2+}, \mathrm{Cd}^{2+}, \mathrm{Ba}^{2+}, \mathrm{Hg}^{2+}, \mathrm{Fe}^{2+}, \mathrm{Co}^{2+}, \mathrm{Fe}^{3+}, \mathrm{Al}^{3+}$ and $\left.\mathrm{Cr}^{3+}\right)$ in $\mathrm{CH}_{3} \mathrm{CN} / \mathrm{HEPES}(4 / 1, v / v$, $\mathrm{pH}=7.4$ ) solution.

\subsection{Fluorescence and UV-Vis Titration Experiments}

To further investigate the chemosensing properties of $\mathbf{L}$, a fluorescence titration of $\mathbf{L}$ with $\mathrm{Co}^{2+}$ was performed. When the $\mathbf{L}$ sensor was titrated with $\mathrm{Co}^{2+}$, the fluorescence intensity was significantly increased up to three equivalents of $\mathrm{Co}^{2+}$, and then no changes were observed up to five equivalents of $\mathrm{Co}^{2+}$ at $450 \mathrm{~nm}$. Changes in the emission intensities of the $\mathbf{L}$ probe $\left(1 \times 10^{-5} \mathrm{~mol} \mathrm{~L}^{-1}\right)$ upon the addition of $\mathrm{Co}^{2+}\left(1 \times 10^{-4} \mathrm{~mol} \mathrm{~L}^{-1}\right)$ are presented in Figure 3. The fluorescence band centered at $450 \mathrm{~nm}$ was progressively increased with the increasing $\mathrm{Co}^{2+}$ concentration, giving a linear concentration range of $0-25 \mu \mathrm{M}$.

From the fluorescence titration profiles, the limit of detection (LOD) of $\mathbf{L}$ for $\mathrm{Co}^{2+}$ was calculated to be $0.26 \mu \mathrm{M}$ based on the equation of $3 \sigma /$ slope [47]. This is lower than the recommended value 
for the U.S. (United States Environmental Protection Agency, secondary drinking water regulation) and Australia (National Health and Medical Research Council). Notably, the LOD is quite low as compared to the data reported regarding to other organic chemosensors for sensing of $\mathrm{Co}^{2+}$ listed in Table 1 [16-25]. The main analytical characteristics of the proposed chemosensor for the determination of $\mathrm{Co}^{2+}$ were compared with those of some previously reported fluorescent chemosensors, including coumarin, diethylenetriamine, oxadiazole, dinitrobenzene-2,2-dipycolylamine, carboxamide, pyrimidine-pyridine and pyrazine-rhodamine. The proposed L fluorescent chemosensor has unique features such as a lower LOD compared with those other detection methods. Therefore, the $\mathbf{L}$ probe is a promising and potential candidate to detect $\mathrm{Co}^{2+}$ ions with high sensitivity.

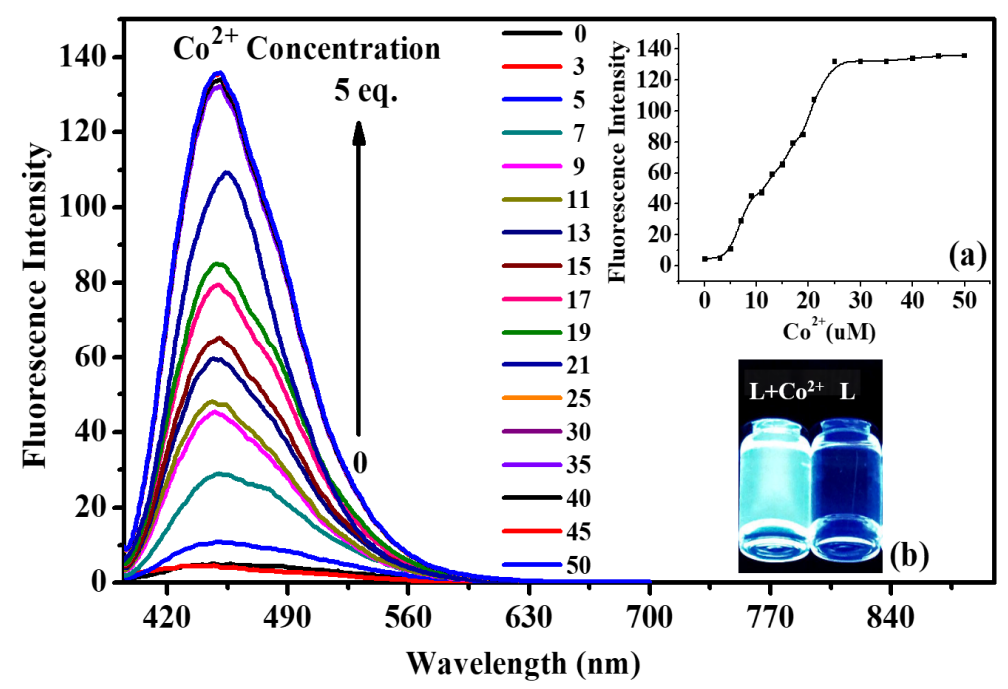

Figure 3. Changes in the fluorescence spectra of $\mathbf{L}\left(1 \times 10^{-5} \mathrm{~mol} \mathrm{~L}^{-1}, \lambda_{\mathrm{ex}}=380 \mathrm{~nm}\right)$ after the addition of increasing amounts of $\mathrm{Co}^{2+}$ (zero-to-five equivalents) in $\mathrm{CH}_{3} \mathrm{CN} / \mathrm{HEPES}(4 / 1, v / v, \mathrm{pH}=7.4)$ at room temperature. Inset: (a) The curve fitting of the fluorescence titration; (b) the color changes observed by UV light of $\mathbf{L}\left(1 \times 10^{-5} \mathrm{~mol} \mathrm{~L}^{-1}\right)$ and upon addition of five equivalents of $\mathrm{Co}^{2+}$ in $\mathrm{CH}_{3} \mathrm{CN} / \mathrm{HEPES}(4 / 1$, $v / v, \mathrm{pH}=7.4)$.

Subsequently, the UV-Vis titration experiments of the $\mathbf{L}$ sensor with $\mathrm{Co}^{2+}$ ions were studied in $\mathrm{CH}_{3} \mathrm{CN} / \mathrm{HEPES}(4 / 1, v / v, \mathrm{pH}=7.4)$ to evaluate the sensing sensitivity of the $\mathbf{L}$ sensor for $\mathrm{Co}^{2+}$ ion; the result is shown in Figure 4. In the titration profile, the UV-Vis absorption band at $510 \mathrm{~nm}$ appeared and decreased gradually with the increasing of $\mathrm{Co}^{2+}$, which resulted from the gradual vanish of intramolecular charge transfer transition mentioned above. A Benesi-Hildebrand plot was drawn using $1 /\left(A-A_{0}\right)$ as a function of $1 /\left[\mathrm{Co}^{2+}\right]$ and showed a linear curve (Figure $\left.\mathrm{S} 1\right)$. The absorption intensity at $510 \mathrm{~nm}$ was linearly related to the $\mathrm{Co}^{2+}$ concentration from one to five equivalents of the $\mathbf{L}$ sensor with a correlation coefficient of $R^{2}=0.99305$, which indicated that the linear range was very wide and in favor of the detection of $\mathrm{Co}^{2+}$ ions. The large correlation coefficient confirmed the 1:1 binding mode between the $\mathbf{L}$ sensor and $\mathrm{Co}^{2+}$, which is consistent with job-plot analysis (vide infra, Figure S2). The associate constant $K_{\mathrm{a}}$ was calculated from the slope and intercept of the line to be $1.2 \times 10^{4} \mathrm{M}^{-1}$, which also indicated that the $\mathbf{L}$ sensor had a large affinity for $\mathrm{Co}^{2+}$ ions. 
Table 1. Comparison of the proposed $\mathbf{L}$ chemosensor with previously reported chemosensors for the determination of $\mathrm{Co}^{2+}$.

Ref.
[16]




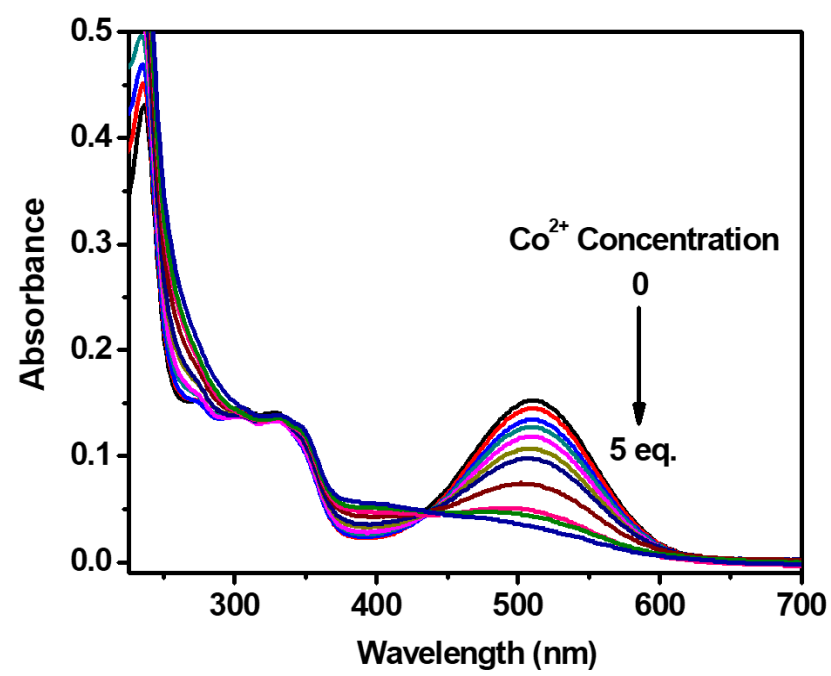

Figure 4. Changes in the UV-Vis spectra of $\mathbf{L}\left(1.0 \times 10^{-5} \mathrm{~mol} \mathrm{~L}^{-1}\right)$ in $\mathrm{CH}_{3} \mathrm{CN} / \mathrm{HEPES}(4 / 1, v / v, \mathrm{pH}=7.4)$ upon titration by $\mathrm{Co}^{2+}$ from $0.5 \times 10^{-5} \mathrm{~mol} \mathrm{~L}^{-1}$ to $5.0 \times 10^{-5} \mathrm{~mol} \mathrm{~L}^{-1}$ at room temperature.

\subsection{Anti-Interference Test from Other Metal Ions}

Selectivity, which represents the relative fluorescence response for the primary cation over other cations, is one of the most important characteristics of a selective chemosensor. To examine the selectivity for $\mathrm{Co}^{2+}$ in a complicated background of potential competing species, the fluorescence enhancement of $\mathbf{L}$ with $\mathrm{Co}^{2+}$ was investigated in the presence of other metal ions (Figure 5). An immediate increase in the emission intensity after the addition of $\mathrm{Co}^{2+}$ ions provided further evidence for the high selectivity of $\mathbf{L}$. The non-fluorescence property of the product of the $\mathbf{L}$ probe $(10 \mu \mathrm{M})$ and five equivalents of $\mathrm{Co}^{2+}$ was scarcely influenced by the presence of 15 equivalents of competing ions. The result revealed that $\mathrm{L}$, as a potential $\mathrm{Co}^{2+}$ fluorescent sensor, could selectively bind with $\mathrm{Co}^{2+}$ in the presence of other metal ions.

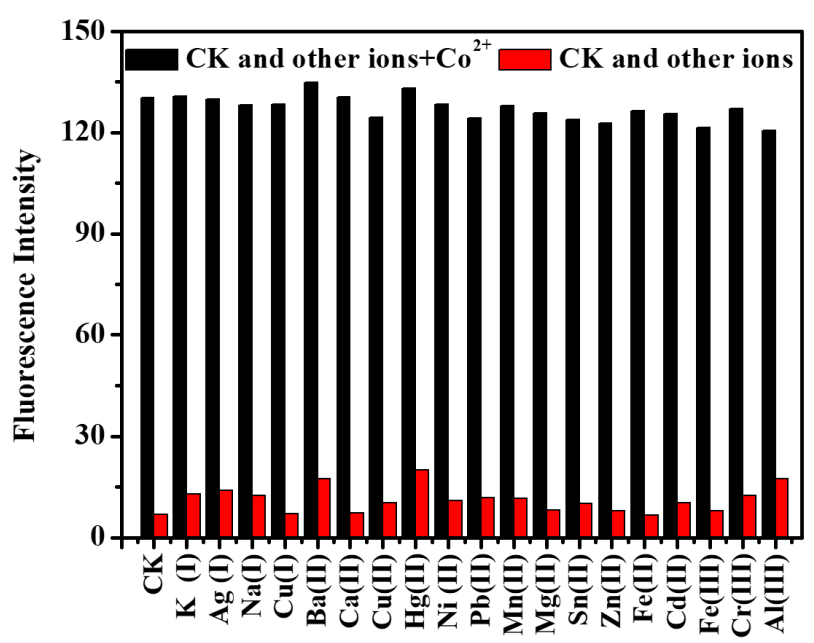

Figure 5. Fluorescence intensity at $450 \mathrm{~nm}$ of $\mathbf{L}\left(1.0 \times 10^{5} \mathrm{~mol} \mathrm{~L}^{-1}\right)$ upon the addition of various metal ions $\left(15.0 \times 10^{5} \mathrm{~mol} \mathrm{~L}^{-1}\right)$ (red bars) and upon the addition of $\mathrm{Co}^{2+}\left(5.0 \times 10^{5} \mathrm{~mol} \mathrm{~L}^{-1}\right)$ with various metal ions $\left(15.0 \times 10^{5} \mathrm{~mol} \mathrm{~L}^{-1}\right)$ (black bars) in $\mathrm{CH}_{3} \mathrm{CN} / \mathrm{HEPES}(4 / 1, v / v, \mathrm{pH}=7.4)\left(\lambda_{\mathrm{ex}}=380 \mathrm{~nm}\right)$.

\subsection{Effect of $p H$}

$\mathrm{pH}$ is a primary factor that affects the probe responses for the purpose of applying to biological and environmental systems. In order to investigate the possibility of using $\mathbf{L}$ in complex media, the fluorescence spectral response of $\mathbf{L}(10 \mu \mathrm{M})$ in the absence and presence of $\mathrm{Co}^{2+}$ (five equivalents) in a 
$\mathrm{CH}_{3} \mathrm{CN} / \mathrm{HEPES}(4: 1, v / v)$ solution at different $\mathrm{pH}$ conditions was evaluated (Figure 6$)$. The enhancement of fluorescence caused by the addition of $\mathrm{Co}^{2+}$ ions was observed in the range of $\mathrm{pH} 4.0-12.0$, thus indicating that the $\mathbf{L}$ chemosensor could be applied in common $\mathrm{pH}$ ranges of environmental analysis, including physiological conditions.

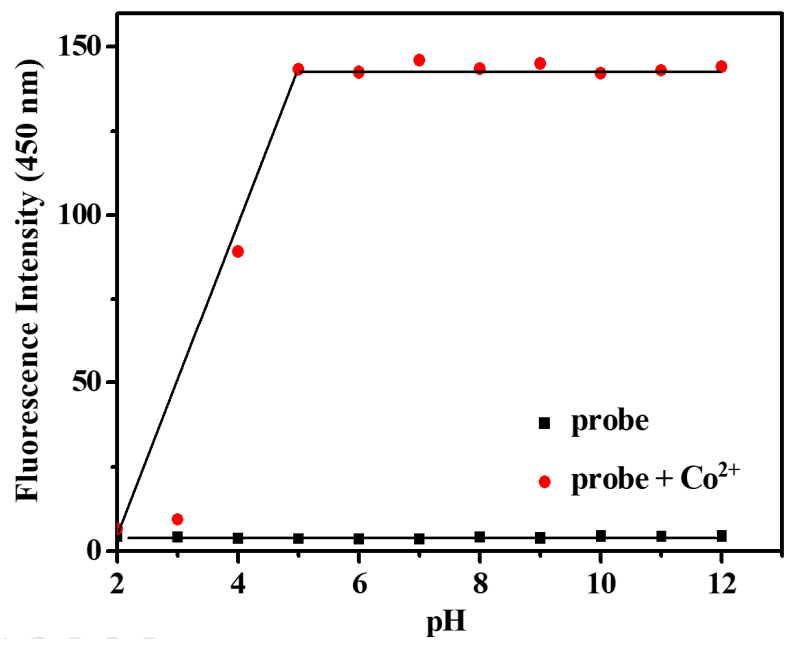

Figure 6. Effect of $\mathrm{pH}$ on the fluorescence intensity $(450 \mathrm{~nm})$ of $\mathbf{L}$ in the absence or presence of five equivalents of $\mathrm{Co}^{2+}$.

\subsection{Job's Plot and Reversibility}

In order to determine the binding stoichiometry of the complex, a job-plot analysis was carried out. The difference in fluorescence intensity at $450 \mathrm{~nm}$ before $\left(I_{0}\right)$ and after $(I)$ the addition of $\mathrm{Co}^{2+}$ $\left(I_{0}-I\right)^{*} X$ was given as ordinate. The difference reached a maximum when the molar fraction $(x)$ of $\mathbf{L}$ was 0.5 (Figure S2). The Job's plot analysis of the reaction between $\mathbf{L}$ and $\mathrm{Co}^{2+}$ with a maximum fluorescence intensity revealed that the stoichiometric ratio was 1:1 in the cobalt complex. Furthermore, the MALDI-TOF MS peak at $m / z 519.173$ corresponding to $\left[\mathrm{Co}(\mathrm{L}-3 \mathrm{H})+\mathrm{H}_{2} \mathrm{O}\right]^{-}$(calculated to be 519.051) further confirms that $\mathbf{L}$ forms a 1:1 complex with $\mathrm{Co}^{2+}$ (Figure S3).

Reversible binding experiments were conducted to justify $\mathbf{L}$ as a chemosensor (Figure S4). The fluorescence intensities of $\mathbf{L}\left(1.0 \times 10^{-5} \mathrm{~mol} \mathrm{~L}^{-1}\right)$ and $\mathrm{Co}^{2+}\left(3.0 \times 10^{5} \mathrm{~mol} \mathrm{~L}^{-1}\right)$ at $450 \mathrm{~nm}$ decreased or increased with the addition of EDTA $\left(3.0 \times 10^{-5} \mathrm{~mol} \mathrm{~L}^{-1}\right)$ and $\mathrm{Co}^{2+}\left(3.0 \times 10^{-5} \mathrm{~mol} \mathrm{~L}^{-1}\right)$ in sequence. The fluorescence changes were nearly reversible after several cycles with the sequentially alternative addition of $\mathrm{Co}^{2+}$ and EDTA (Figure S5). Thus, through treatment with a proper reagent EDTA, the L sensor could be simply recyclable toward $\mathrm{Co}^{2+}$. Such reversibility and regeneration of the $\mathbf{L}$ sensor could be applicable for the fabrication of a chemosensor to sense $\mathrm{Co}^{2+}$.

\subsection{Sensing Mechanism}

To further study the possible binding mode of $\mathbf{L}$ and $\mathrm{Co}^{2+}$, IR spectroscopy was employed to elucidate the coordination mode. Figure 7 shows the comparison of IR spectra of $\mathbf{L}$ before and after the addition of $\mathrm{Co}^{2+}$. With the introduction of $\mathrm{Co}^{2+}$, the sharp peaks at 3391 and $3304 \mathrm{~cm}^{-1}$ disappeared. These results suggested that the aromatic amine might involve in the coordination of the $\mathbf{L}$ complex and $\mathrm{Co}^{2+}$, which is consistent with the previous UV analysis. Moreover, the carbonyl groups in the imide moiety may stabilize the complex [48]. As depicted in Scheme 1, it is worth noting that the detecting metal ions of chemosensor BTBN were $\mathrm{Fe}^{3+}$ and $\mathrm{Pb}^{2+}$, whose proposed sensing mechanism was involved in the nitrogen and sulfur atoms. However, the $\mathbf{L}$ probe with a similar structure to BTBN (differing merely in one more carbonyl group) detected $\mathrm{Co}^{2+}$ with high selectivity and sensitivity. The result indicated the oxygen atom of the carbonyl group of $\mathbf{L}$ should participate in coordination with $\mathrm{Co}^{2+}$. 


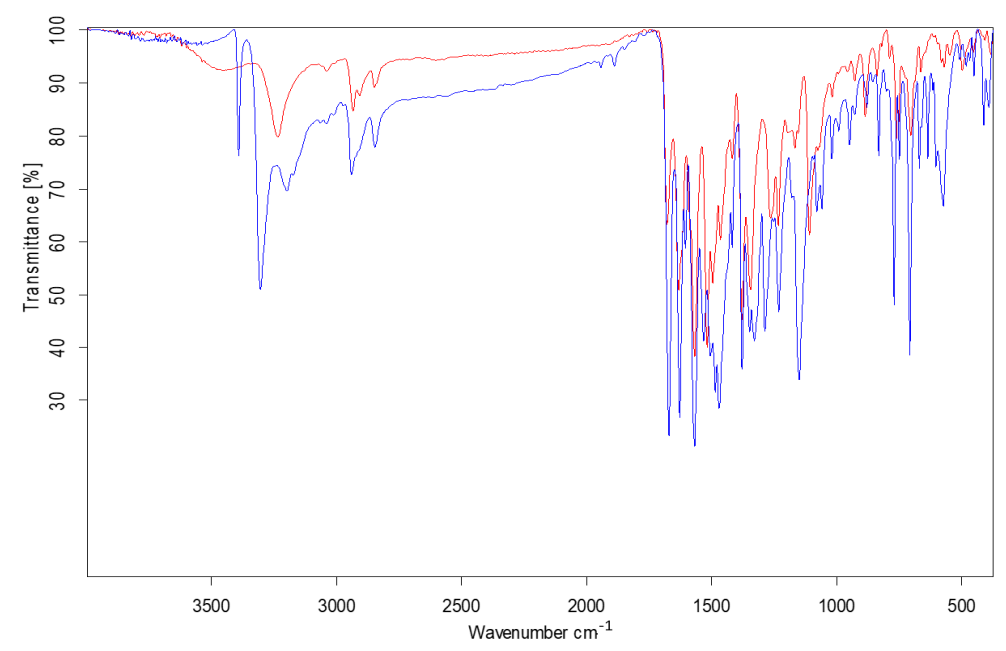

Figure 7. IR spectra of the $\mathbf{L}$ compound before (blue) and after (red) the addition of $\mathrm{Co}^{2+}$.

Since the ${ }^{1} \mathrm{H}$ NMR titration of the $\mathrm{L}-\mathrm{Co}^{2+}$ complex could not be measured in instruments, density functional theory (DFT) theoretical calculations of $\mathbf{L}$ and $\mathbf{L}-\mathrm{Co}^{2+}$ were performed in parallel to experimental study using the Gaussian 09 program to address this issue. Because UV-Vis titration and Job's plot analyses indicated a 1:1 stoichiometric ratio of $\mathbf{L}$ reacting with $\mathrm{Co}^{2+}$, theoretical calculations were performed under the 1:1 combination. The structures of $\mathbf{L}$ and $\mathbf{L}-\mathrm{Co}^{2+}$ were optimized using B3LYP and B3LYP/LanL2DZ basis sets, respectively (Figure 8). The energy minimized structure of $\mathbf{L}$ showed a bent structure with a dihedral angle of $61.5^{\circ}$ between thiourea and naphthalimide (Figure $8 \mathrm{a}$ ). However, the $\mathrm{L}^{-\mathrm{Co}^{2+}}$ complex exhibited a relatively planar structure due to the coordination of $\mathrm{Co}^{2+}$, which could change intramolecular torsion to some extent (Figure 8b). The results confirmed the RIM and CHEF effects for $\mathrm{L}_{-} \mathrm{Co}^{2+}$, as mentioned above. Moreover, the frontier molecular orbital analysis reveals that in the L HOMO probe is located over the thiourea unit and a large portion of naphthalimide, whereas the LUMO is spread over the naphthalimide unit and a large portion of thiourea, which shows a small degree of orbital separation and provided feasibility of the ICT process (Figure 9a). However, HOMO and LUMO both appear mainly over the coordinate ring and the naphthalimide group with large overlap in ${\mathrm{L}-\mathrm{Co}^{2+}}^{2+}$ (Figure 9b). Usually, the wavefunctions of the electron in the HOMO and that in the LUMO overlap significantly, resulting in a large oscillator strength in the normal local excited-state that is suited to producing high-efficiency florescence radiation due to the large orbital overlap [49]; this results in the fluorescence enhancement of $\mathbf{L}-\mathrm{Co}^{2+}$. The calculated HOMO-LUMO energy gap for the $\mathbf{L}$ probe $(3.5810 \mathrm{eV})$ was more than that of the $\mathrm{L}^{-\mathrm{Co}^{2+}}(2.8920 \mathrm{eV})$, which also indicates a favorable coordination between the $\mathbf{L}$ probe and $\mathrm{Co}^{2+}$. From these observations, it can be further confirmed that ICT and PET could occur between the electron-releasing amino group in thiourea and the electron-withdrawing $\mathrm{C}=\mathrm{O}$ group in naphthalimide, as stated above, which induces a fluorescence turn off for the $\mathbf{L}$ probe. The changes in charge density on the $\mathrm{N}$-binding sites of $\mathbf{L}$ after complexion with $\mathrm{Co}^{2+}$ inhibited the PET and ICT process and hence resulted in a fluorescence turn on with slight blue-shift.

Photoinduced electron transfer (PET) from a donor (D) to an acceptor (A) leads to the formation of a charge-separated state consisting of the donor radical cation and the acceptor radical anion [50,51]. Frontier molecular orbital calculations along with optical experiments on both ON and OFF states are presented in this study (Figures 2, 9 and 10). The molecular structure of the $\mathbf{L}$ probe is shown in Figure 10a and consists of a D group (thiourea) and an A group (naphthalimide) and meets the general accepted mechanism of an intramolecular PET fluorescent probe (D-A) (Figure 10b) [52,53]. In Figure 10c, the schematic frontier molecular orbital diagrams for PET and its energetic requirements are shown where in the OFF state (up), the HOMO level corresponds to the D-based orbital, so the PET is thermodynamically feasible; in the ON state (down), the HOMO level is the A-based orbital, so the PET is not plausible. Thus, the distribution of HOMO and LUMO for L (Figure 9) clarifies the 
PET-sensing mechanism combined with that shown in Figure 10c. Based on the aforementioned results and the literature $[38,54,55]$, the proposed binding mode is shown in Scheme 2.
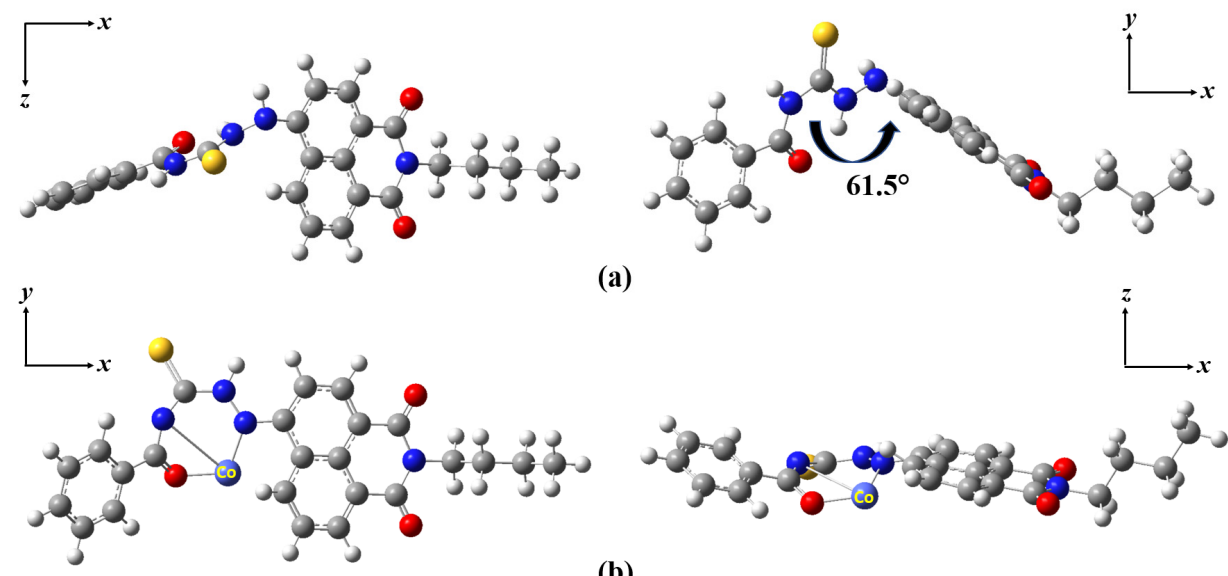

(a)

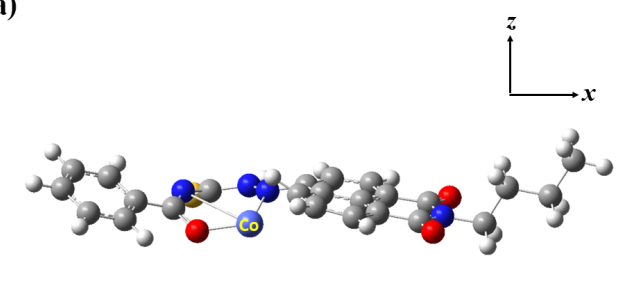

(b)

Figure 8. The energy-minimized structures of (a) $\mathbf{L}$ and (b) the $\mathbf{L}-\mathrm{Co}^{2+}$ complex.

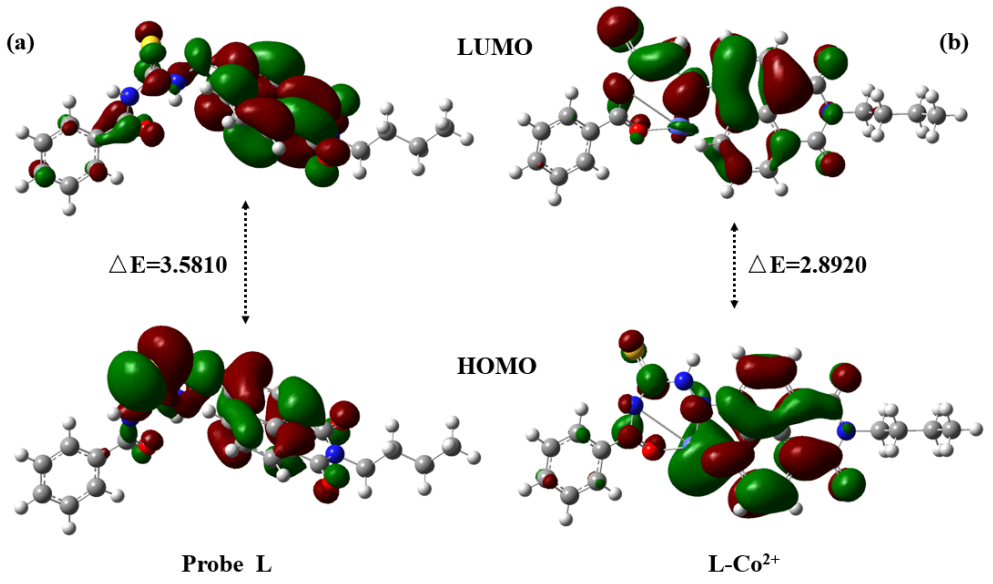

Figure 9. Frontier molecular orbital of (a) the $\mathbf{L}$ probe and (b) $\mathrm{L}^{-\mathrm{Co}^{2+}}$.

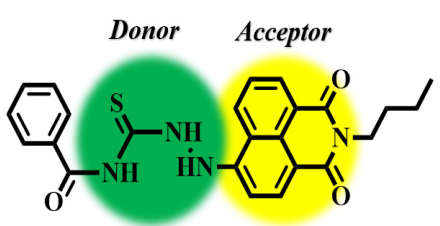

(a)

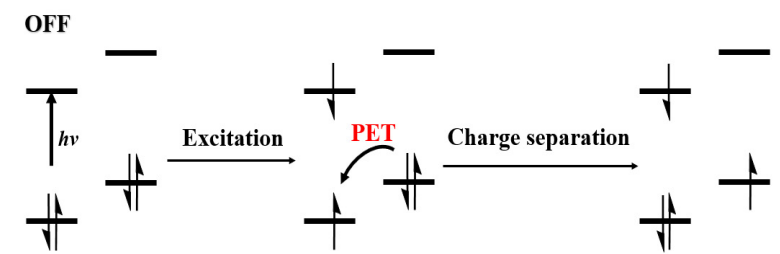

A D

D

A $^{*} \quad$ D

$\mathbf{A}^{-} \cdot \mathbf{D}^{+}$.

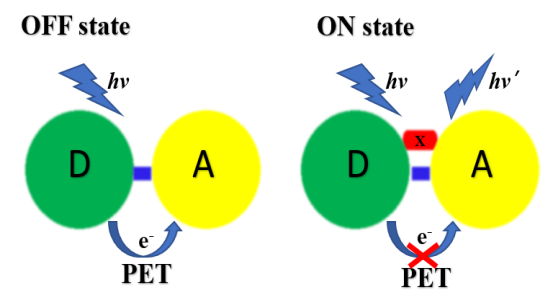

(b)

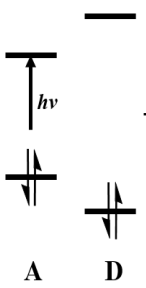

A D

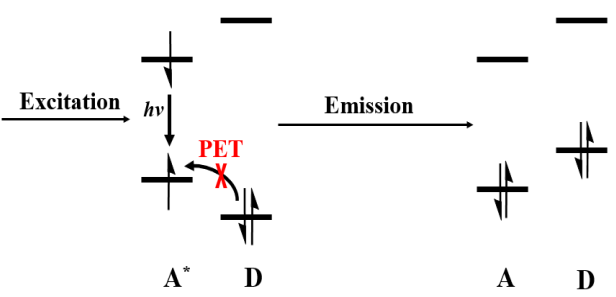

(c)

Figure 10. (a) Design strategy of the target L probe. (b) Photoinduced electron transfer (PET) in the analyte-free D-A system creates the OFF state (left); the addition of an analyte (X) blocks the PET mechanism and activates the fluorescence emission, resulting in the ON state. (c) Frontier molecular orbital energy diagrams of the OFF (up) and ON (down) states of an A-D System. 


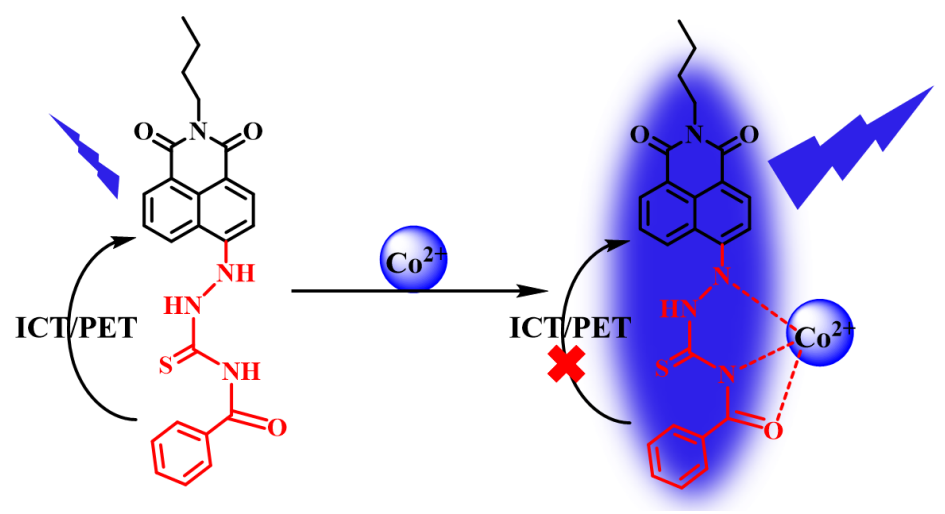

Scheme 2. Possible sensing mechanism of $\mathrm{Co}^{2+}$ by $\mathbf{L}$ and proposed structure of the $\mathbf{L}-\mathrm{Co}^{2+}$ complex.

\subsection{Cell Imaging}

Since low cell toxicity is a key feature for living cell imaging, the cytotoxicity of $\mathbf{L}$ was examined by an MTT assay with $\mathbf{L}$ concentrations from 0 to $30 \mu \mathrm{M}$. As shown in Figure S6, even the living cells incubated with $20 \mu \mathrm{M}$ of $\mathbf{L}$ for $24 \mathrm{~h}$ still kept high survival rate. This result suggest that $\mathbf{L}$ is suitable for applications in biological systems.

Finally, we further tested the capability of the $\mathbf{L}$ probe to detect $\mathrm{Co}^{2+}$ in HepG2 cells. The HepG2 cells were incubated with $\mathbf{L}(10 \mu \mathrm{M})$ for $30 \mathrm{~min}$ at $37^{\circ} \mathrm{C}$. Simultaneously, the cells were further raised with different concentrations of $\mathrm{Co}^{2+}$ for $30 \mathrm{~min}$ and then subjected to images. HepG2 cells treated with $\mathbf{L}$ were shown in Figure 11. After the addition of $25 \mu \mathrm{M} \mathrm{Co}^{2+}$, a remarkable fluorescence signal could be observed (Figure 11), which was consistent with the titration experiment. Meanwhile, fluorescence imaging figure corresponding bright-field image had a good coincidence degree. Merged images of fluorescence and bright-field images showed that the fluorescence signals were localized in the intracellular area, indicating a subcellular distribution of $\mathrm{Co}^{2+}$ and a good cell-membrane permeability of the $\mathbf{L}$ chemosensor. As shown in Figure 11, this proved that the cells were viable during the experiments. This result indicated that the $\mathbf{L}$ compound could be effectively used for cell imaging and detected the presence of $\mathrm{Co}^{2+}$ in vivo.

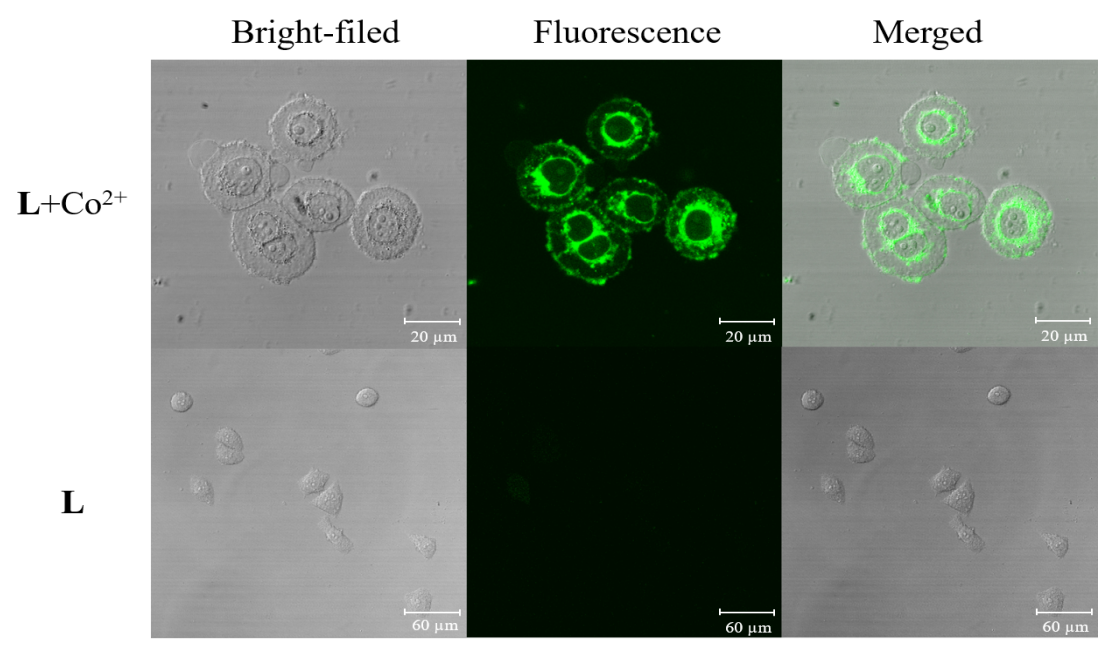

Figure 11. Fluorescence images of HepG2 cells treated with the $\mathbf{L}$ probe and $\mathrm{Co}^{2+}$. Bright-field image (left); fluorescence image $\left(\lambda_{\mathrm{ex}}=380 \mathrm{~nm}\right)$ (middle); and merged image of bright-field and fluorescence image (right). 


\section{Experimental Section}

\subsection{Materials and Instrumentation}

All solvents and reagents were commercially available, and they were used without purification. The FT-IR spectra were recorded on a Bruker ALPHA-T spectrometer (Bruker, Bremen, Germany). The ${ }^{1} \mathrm{H}$ NMR and ${ }^{13} \mathrm{C}$ NMR spectra were recorded on a Bruker AVANVE $400 \mathrm{MHz}$ spectrometer (Bruker, Bremen, Germany). The high-resolution mass spectrometry (HRMS) was recorded on an FTMS Ultral Apex MS spectrometer (Bruker Daltonics Inc, Colorado Springs, CO, USA). Absorption spectra were collected using a UV-2550 ultraviolet spectrophotometer (Shimadzu, Kyoto, Japan). Fluorescence spectra were obtained using a PerkinElmer LS55 fluorescence spectrometer (PerkinElmer, London, $\mathrm{UK}$ ). The $\mathrm{pH}$ values were measured on a PHS-3C pH meter (Inesa, Beijing, China).

\subsection{Synthesis of Compound $L$}

As shown in Scheme 3, Compounds 1 and 2 were synthesized following a procedure reported before [56,57]. Compound $\mathbf{L}$ was synthesized according to a reported method [38] where the final 1,8-naphthalimide derivative could be synthesized via three steps (Scheme 3). A mixture of Compound $2(0.49 \mathrm{~g}, 2.2 \mathrm{mmol})$ and benzoyl isothiocyanate $(0.43 \mathrm{~g}, 2.65 \mathrm{mmol})$ was added into $30 \mathrm{~mL}$ acetonitrile in a round-bottom flask and was refluxed for $4 \mathrm{~h}$. The solution was then cooled to room temperature, and the orange precipitate was filtered out and purified by recrystallization from acetonitrile with high yield of $63 \%$. The molecular structure of synthetic compounds was precisely confirmed by FT-IR, ${ }^{1} \mathrm{H}$ NMR, ${ }^{13} \mathrm{C}$ NMR, and ESI-MS spectroscopies (Figures S7-S16).

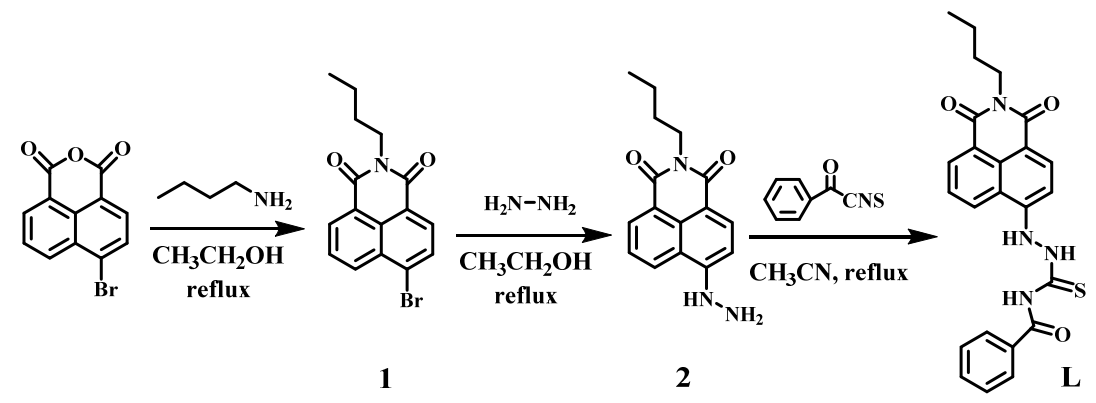

Scheme 3. Synthetic approach to the $\mathbf{L}$ chemosensor.

$\mathrm{N}$-(2-(2-butyl-1,3-dioxo-2,3-dihydro-1H-benzo[de]isoquinolin-6-yl)hydrazine-1-carbonothioyl) benzamide (L): HRMS (ESI): $m / z$ calculated for $\mathrm{C}_{24} \mathrm{H}_{22} \mathrm{~N}_{4} \mathrm{O}_{3} \mathrm{~S}(\mathrm{M}+\mathrm{H})^{+}$: 447.1413; found 447.1482; ${ }^{1} \mathrm{H}-\mathrm{NMR}\left(400 \mathrm{MHz}, \mathrm{DMSO}-d_{6}\right): \delta 12.21(\mathrm{~s}, \mathrm{Ar}-\mathrm{NH}, 1 \mathrm{H}), 11.75(\mathrm{~s}, \mathrm{~N}-\mathrm{NH}, 1 \mathrm{H}), 10.07(\mathrm{~s}, \mathrm{C}-\mathrm{NH}-\mathrm{C}, 1 \mathrm{H})$, 8.80-7.01(m, Ar-H, 10H), $4.02\left(\mathrm{t}, J=7.0 \mathrm{~Hz}, \mathrm{~N}-\mathrm{CH}_{2}, 2 \mathrm{H}\right), 1.62-1.59\left(\mathrm{~m}, \mathrm{C}-\mathrm{CH}_{2}, 2 \mathrm{H}\right), 1.37-1.32(\mathrm{~m}$, $\left.\mathrm{C}-\mathrm{CH}_{2}, 2 \mathrm{H}\right), 0.91\left(\mathrm{t}, J=7.2 \mathrm{~Hz}, \mathrm{C}-\mathrm{CH}_{3}, 3 \mathrm{H}\right) ;{ }^{13} \mathrm{C}-\mathrm{NMR}\left(100 \mathrm{MHz}, \mathrm{DMSO}-d_{6}\right): \delta: 182.88,167.57,164.11$, 163.42, 149.46, 133.87, 133.63, 132.510, 132.51, 131.36, 131.36, 129.42, 129.30, 129.02, 128.96, 125.70, $122.56,119.54,111.91,106.16,40.62,30.27,20.32$, and 14.25 .

\subsection{Testing and Calculating Methods}

The stock solution of the $\mathbf{L}$ probe $\left(10^{-4} \mathrm{M}\right)$ was prepared in $\mathrm{CH}_{3} \mathrm{CN} / \mathrm{HEPES}(4 / 1, v / v, \mathrm{pH}=7.4)$. The salts used in stock solutions of metal ions with deionized water were $\mathrm{KCl}, \mathrm{NaCl}, \mathrm{MgCl}_{2}, \mathrm{ZnCl}_{2}$, $\mathrm{FeCl}_{3}, \mathrm{SnCl}_{2}, \mathrm{CaCl}_{2}, \mathrm{Al}\left(\mathrm{NO}_{3}\right)_{3}, \mathrm{CuCl}_{2}, \mathrm{NiCl}_{2}, \mathrm{MnCl}_{2}, \mathrm{CrCl}_{3}, \mathrm{PbCl}_{2}, \mathrm{BaCl}_{2}, \mathrm{CoCl}_{2}$.

During the spectroscopic determination, a stock solution of $\mathbf{L}$ was diluted with acetonitrile to a final test concentration of $1 \times 10^{-5} \mathrm{M}$. Test solutions for selectivity experiments were prepared by placing $10 \mathrm{~mL}$ of the $\mathbf{L}$ solution $\left(1 \times 10^{-5} \mathrm{M}\right)$ into volumetric flasks followed by adding $50 \mu \mathrm{L}$ of each metal ion stock solution $(0.01 \mathrm{M})$ with micropipette. The vials were shaken for a few seconds, and then the absorption and fluorescence spectra were recorded. Test solutions for titration experiments 
were prepared by placing $10 \mathrm{~mL}$ of the $\mathbf{L}$ solution $\left(1 \times 10^{-5} \mathrm{M}\right)$ into volumetric flasks followed by adding an appropriate different molar ratio of the $\mathrm{Co}^{2+}$ stock solution $(0.01 \mathrm{M})$ with a micropipette. The vials were shaken for a few seconds, and the absorption and fluorescence spectra were recorded. The excitation wavelength was $380 \mathrm{~nm}$ for all measurements of fluorescence spectra, and the excitation and emission slit widths were 10 and $10 \mathrm{~nm}$, respectively. The $\mathrm{pH}$ was adjusted to 7.4 through the $\mathrm{NaOH}$ solution $(1.0 \mathrm{M})$. In the experiment of $\mathrm{pH}$ effect of $\mathbf{L}$ toward $\mathrm{Co}^{2+}, \mathrm{pH}$ adjustment was made with dilute hydrochloric acid and sodium hydroxide.

\subsection{Theoretical Calculations Methods}

Quantum chemical calculations for ground state optimized structures were conducted by density functional theory (DFT) in a Gaussian 09W program package. The ground state structural elucidation were optimized using DFT-based B3LYP functional where 6-31G(d,p) and LANL2DZ basis sets were used for $\mathbf{L}$ and a model [L-Co(II)] complex, respectively.

\subsection{Cell Incubation and Cell Imaging}

HepG-2 cells were cultured in a $1 \times$ SPP medium $(0.003 \%$ EDTA ferric sodium salt, $0.1 \%$ yeast extract, $0.2 \%$ glucose, $1 \%$ proteose peptone) at $37{ }^{\circ} \mathrm{C}$. Plated on 6 -well plates, the HepG-2 cells were allowed to adhere for $12 \mathrm{~h}$. Afterwards, in order to remove the culture solution, the cells were washed with a phosphate buffer saline (PBS) butter and incubated with the $\mathbf{L}$ probe $(0.5 \mu \mathrm{M})$. After pretreatment for $20 \mathrm{~min}$ at $37^{\circ} \mathrm{C}$, excess, the L probe was gently washed with the PBS butter three times and incubated with $\mathrm{Co}^{2+}(10 \mu \mathrm{M})$ for a further $20 \mathrm{~min}$ at an indoor temperature. After washing cells with a prewarmed PBS buffer three times, cell imaging was then carried out. The fluorescence was collected by a Nikon A1 confocal laser microscopy system (Nikon, Japan), and fluorescence images were recorded at green channel.

\section{Conclusions}

In summary, a new chemosensor for $\mathrm{Co}^{2+}$ based on 1,8-naphthalimide appending thiourea was successfully designed and synthesized. The $\mathbf{L}$ probe was essentially insensitive to protons over a wide range of $\mathrm{pH}(4.0-12.0)$ while retaining high selectivity and sensitivity toward $\mathrm{Co}^{2+}$ in $\mathrm{CH}_{3} \mathrm{CN} / \mathrm{HEPES}$ $(4 / 1, v / v, \mathrm{pH}=7.4)$. L displayed a "turn on" fluorescence emission and a colorimetric response in the presence of $\mathrm{Co}^{2+}$, which relied on the binary effects of PET and ICT. It was found that $\mathbf{L}$ has a low detection limit of $0.26 \mu \mathrm{M}$ for $\mathrm{Co}^{2+}$, which is lower than that of many reported organic chemosensors, and a large number of biologically relevant metal ions exhibited no substantial interference. The UV-Vis titration and Job's Plot analysis indicated that the complexation stoichiometry between $\mathbf{L}$ and $\mathrm{Co}^{2+}$ was 1:1. Moreover, $\mathbf{L}$ showed outstanding cell permeation and almost no toxicity upon the selective detection of $\mathrm{Co}^{2+}$ in living cells, leading to the possibility of its application as a highly selective probe for biological systems. We expect that the present strategy can provide inspiration for the design of new types of chemosensors for $\mathrm{Co}^{2+}$ in biological systems.

Supplementary Materials: The supplementary materials are available online.

Author Contributions: Y.F. and Y.-L.L. developed the concept of the work. L.Y. and L.L. carried out the synthetic work. Y.-Q.G. contributed reagents, materials and analytical tools. X.-X.P. conducted the fluorescence properties assay. The computational work was accomplished by P.L. The manuscript was written jointly by Y.F. and Y.-L.L., F.Y. revised the paper.

Funding: The work was supported by the Natural Science Foundation of Heilongjiang Province (LH2019B002), Postdoctoral Science Foundation of Heilongjiang Province (LBH-Z17014), and Young Talent Plan of Northeast Agricultural University (17QC24).

Conflicts of Interest: The authors declare no conflict of interest. 


\section{References}

1. Weller, D.; Brändle, H.; Gorman, G.; Lin, C.J.; Notarys, H. Magnetic and magneto-optical properties of cobalt-platinum alloys with perpendicular magnetic anisotropy. App. Phys. Lett. 1992, 61, 2726-2728. [CrossRef]

2. Amatucci, G.G.; Tarascon, J.M.; Klein, L.C. Cobalt dissolution in $\mathrm{LiCoO}_{2}$-based non-aqueous rechargeable batteries. Solid State Ion. 1996, 83, 167-173. [CrossRef]

3. Wakabayashi, K.; Yorimitsu, H.; Oshima, H. Cobalt-catalyzed tandem radical cyclization and cross-coupling reaction: Its application to benzyl-substituted heterocycles. J. Am. Chem. Soc. 2001, 123, 5374-5375. [CrossRef] [PubMed]

4. Gray, H.B. Biological inorganic chemistry at the beginning of the 21st century. Proc. Natl. Acad. Sci. USA 2003, 100, 3563-3568. [CrossRef]

5. Okamoto, S.; Eltis, L.D. The biological occurrence and trafficking of cobalt. Metallomics 2011, 3, 963-970. [CrossRef]

6. Kim, B.E.; Nevitt, T.; Thiele, D.J. Mechanisms for copper acquisition, distribution and regulation. Nat. Chem. Biol. 2008, 4, 176-185. [CrossRef]

7. Basketter, D.A.; Angelini, G.; Ingber, A.; Kern, P.S.; Menné, T. Nickel, chromium and cobalt in consumer products: Revisiting safe levels in the new millennium. Contact Dermat. 2003, 49, 1-7. [CrossRef]

8. Shirakawa, T.; Fujimura, N.; Kato, M.; Morimoto, K. Occupational asthma from cobalt sensitivity in workers exposed to hard metal dust. Chest 1989, 95, 29-37. [CrossRef]

9. Agency for Toxic Substances and Disease Registry (ATSDR). Toxicological Profile for Cobalt; Public Health Service, U.S. Department of Health and Human Services: Atlanta, GA, USA, 1992.

10. Khorrami, A.R.; Fakhari, A.R.; Shamsipur, M.; Naeimi, H. Pre-concentration of ultra trace amounts of copper, zinc, cobalt and nickel in environmental water samples using modified C18 extraction disks and determination by inductively coupled plasma-optical emission spectrometry. Environ. Anal. Chem. 2009, 89, 319-329. [CrossRef]

11. Shokou, N.; Shemirani, F.; Memarzadeh, F. Fiber optic-linear array detection spectrophotometry in combination with cloud point extraction for simultaneous preconcentration and determination of cobalt and nickel. Anal. Chim. Acta 2007, 601, 204-211. [CrossRef]

12. Homola, J.; Yee, S.S.; Gauglitz, G. Surface plasmon resonance sensors: Review. Sens. Actuators B Chem. 1999, 54, 3-15. [CrossRef]

13. Tsoutsi, D.; Guerrini, L.; Hermida-Ramon, J.M.; Giannini, V.; Liz-Marzan, L.M.; Wei, A.; Alvarez-Puebla, R.A. Simultaneous SERS detection of copper and cobalt at ultratrace levels. Nanoscale 2013, 5, 5841-5846. [CrossRef]

14. Lok, K.S.; Lee, P.P.F.; Kwok, Y.C.; Nguyen, N.T. Rapid determination of vitamin $B_{12}$ concentration with a chemiluminescence lab on a chip. Lab Chip 2012, 12, 2353-2361. [CrossRef]

15. Mashraqui, S.H.; Chandiramani, M.; Betkar, R.; Poonia, K. A simple internal charge transfer probe offering dual optical detection of Co(II) via color and fluorescence modulations. Tetrahedron Lett. 2010, 51, 1306-1308. [CrossRef]

16. Vashisht, D.; Kaur, K.; Jukaria, R.; Vashisht, A.; Sharma, S.; Mehta, S.K. Colorimetric chemosensor based on coumarin skeleton for selective naked eye detection of cobalt(II) ion in near aqueous medium. Sens. Actuators B Chem. 2019, 280, 219-226. [CrossRef]

17. Lee, S.Y.; Kim, S.Y.; Kim, J.A.; Kim, C. A dual chemosensor: Colorimetric detection of $\mathrm{Co}^{2+}$ and fluorometric detection of $\mathrm{Zn}^{2+}$. J. Lumin. 2016, 179, 602-609. [CrossRef]

18. Wang, L.; Gong, X.; Bing, Q.J. A new oxadiazole-based dual-mode chemosensor: Colorimetric detection of $\mathrm{Co}^{2+}$ and fluorometric detection of $\mathrm{Cu}^{2+}$ with high selectivity and sensitivity. Microchem. J. 2018, 142, 279-287. [CrossRef]

19. Liu, Z.D.; Wang, W.L.; Xu, H.J.; Sheng, L.Q.; Chen, S.S.; Huang, D.Q.; Sun, F. A "naked eye" and ratiometric chemosensor for cobalt(II) based on coumarin platform in aqueous solution. Inorg. Chem. Commun. 2015, 62, 19-23. [CrossRef]

20. Ryu, K.Y.; Lee, S.Y.; Park, D.Y.; Kim, S.Y.; Kim, C. A novel colorimetric chemosensor for detection of Co ${ }^{2+}$ and $S^{2-}$ in an aqueous environment. Sens. Actuators B Chem. 2016, 242, 792-800. [CrossRef] 
21. Sohrabi, M.; Amirnasr, M.; Meghdadi, S.; Lutz, M.; Torbati, M.B.; Farrokhpour, H. A highly selective fluorescence turn-on chemosensor for $\mathrm{Zn}^{2+}$, and its application in live cell imaging, and as a colorimetric sensor for $\mathrm{Co}^{2+}$ : Experimental and TD-DFT calculations. New J. Chem. 2018, 42, 12595-12606. [CrossRef]

22. Na, Y.J.; Choi, Y.W.; You, G.R.; Kim, C. A novel selective colorimetric chemosensor for cobalt ions in a near perfect aqueous solution. Sens. Actuators B Chem. 2016, 223, 234-240. [CrossRef]

23. Jung, J.M.; Lee, S.Y.; Kim, C. A novel colorimetric chemosensor for multiple target metal ions $\mathrm{Fe}^{2+}, \mathrm{Co}^{2+}$, and $\mathrm{Cu}^{2+}$ in a near-perfect aqueous solution: Experimental and theoretical studies. Sens. Actuators B Chem. 2017, 251, 291-301. [CrossRef]

24. Lee, S.Y.; Lee, J.J.; Bok, K.H.; Kim, S.Y.; Kim, C. Highly selective and sensitive colorimetric chemosensor for detection of $\mathrm{Co}^{2+}$ in a near-perfect aqueous solution. RSC Adv. 2016, 6, 28081-28088. [CrossRef]

25. Liu, K.; Guo, P.; Liu, L.J.; Shi, X.F. Fluorescence enhancement of a novel pyrazine coupled rhodamine derivative for the paramagnetic $\mathrm{Co}^{2+}$ detection. Sens. Actuators B Chem. 2017, 250, 667-672. [CrossRef]

26. Chen, H.; Yuan, F.; Xu, J.; Zhang, Y.; Wu, Y.; Wang, L. Simple and sensitive detection method for Cobalt(II) in water using $\mathrm{CePO}_{4}: \mathrm{Tb}^{3+}$ nanocrystals as fluorescent probes. Spectrochim. Acta Part A 2013, 107, 151-155. [CrossRef]

27. Zi, L.; Huang, Y.; Yan, Z.; Liao, S. Thioglycolic acid-capped $\mathrm{CuInS}_{2} / \mathrm{ZnS}$ quantum dots as fluorescent probe for cobalt ion detection. J. Lumin. 2014, 148, 359-363. [CrossRef]

28. Zhao, L.; Li, H.Y.; Liu, H.C.; Liu, M.T.; Huang, N.; He, Z.Y.; Li, Y.; Chen, Y.H.; Ding, L. Microwave-assisted facile synthesis of polymer dots as a fluorescent probe for detection of cobalt(II) and manganese(II). Anal. Bioanal. Chem. 2019, 411, 2373-2381. [CrossRef]

29. Mohandoss, S.; Stalin, T. A new fluorescent PET sensor probe for $\mathrm{Co}^{2+}$ ion detection: Computational, logic device and living cell imaging applications. RSC Adv. 2017, 7, 16581-16593. [CrossRef]

30. Fu, Y.L.; Fan, C.B.; Liu, G.; Pu, S.Z. A colorimetric and fluorescent sensor for $\mathrm{Cu}^{2+}$ and $\mathrm{F}^{-}$based on a diarylethene with a 1,8-naphthalimide Schiff base unit. Sens. Actuators B Chem. 2017, 239, 295-303. [CrossRef]

31. Zhang, J.F.; Zhou, Y.; Yoon, J.; Kim, Y.; Kim, S.J.; Kim, J.S. Naphthalimide modified rhodamine derivative: Ratiometric and selective fluorescent sensor for $\mathrm{Cu}^{2+}$ based on two different approaches. Org. Lett. 2010, 12, 3852-3855. [CrossRef]

32. Liu, T.Y.; Xu, Z.C.; Spring, D.R.; Cui, J.N. A lysosome-targetable fluorescent probe for imaging hydrogen sulfide in living cells. Org. Lett. 2013, 15, 2310-2313. [CrossRef]

33. Karagöz, E.; Varol, S.F.; Sayin, S.; Merdan, Z. Electrical characterization of two analogous Schottky contacts produced from N-substituted 1,8-naphthalimide. Phys. Chem. Chem. Phys. 2018, 20, 30502-30513. [CrossRef]

34. Ye, F.; Liang, X.M.; Wu, N.; Li, P.; Chai, Q.; Fu, Y. A new perylene-based fluorescent pH chemosensor for strongly acidic condition. Spectrochim. Acta A 2019, 216, 359-364. [CrossRef]

35. Fu, Y.; Pang, X.X.; Wang, Z.Q.; Chai, Q.; Ye, F. A highly sensitive and selective fluorescent probe for determination of $\mathrm{Cu}(\mathrm{II})$ and application in live cell imaging. Spectrochim. Acta A 2019, 208, 198-205. [CrossRef]

36. Ye, F.; Wu, N.; Li, P.; Liu, Y.L.; Li, S.J.; Fu, Y. A lysosome-targetable fluorescent probe for imaging trivalent cations $\mathrm{Fe}^{3+}, \mathrm{Al}^{3+}$ and $\mathrm{Cr}^{3+}$ in living cells. Spectrochim. Acta A 2019, 222, 117242. [CrossRef]

37. Ye, F.; Liang, X.M.; Xu, K.X.; Pang, X.X.; Chai, Q.; Fu, Y. A novel dithiourea-appended naphthalimide "on-off" fluorescent probe for detecting $\mathrm{Hg}^{2+}$ and $\mathrm{Ag}^{+}$and its application in cell imaging. Talanta 2019, 200, 494-502. [CrossRef]

38. Zhang, Y.Z.; Lu, S.Z.; Sha, C.M.; Xu, D.M. A single thiourea-appended 1,8-naphthalimide chemosensor for three heavy metal ions: $\mathrm{Fe}^{3+}, \mathrm{Pb}^{2+}$, and $\mathrm{Hg}^{2+}$. Sens. Actuators B Chem. 2015, 208, 258-266. [CrossRef]

39. Vonlanthen, M.; Finney, N.S. Thioureas as reporting elements for metal-responsive fluorescent chemosensors. J. Org. Chem. 2013, 78, 3980-3988. [CrossRef]

40. Alaei, P.; Rouhani, S.; Gharanjig, K.; Ghasemi, J. A new polymerizable fluorescent PET chemosensor of fluoride (F-) based on naphthalimide-thiourea dye. Spectrochim. Acta A 2012, 90, 85-92. [CrossRef]

41. Tang, Y.H.; Kong, X.Q.; Xu, A.; Dong, B.L.; Lin, W.Y. Development of a two-photon fluorescent probe for imaging of endogenous formaldehyde in living tissues. Angew. Chem. Int. Ed. 2016, 55, 3356-3359. [CrossRef]

42. Grabowski, Z.R.; Rotkiewicz, K.; Rettig, W. Structural changes accompanying intramolecular electron transfer: Focus on twisted intramolecular charge-transfer states and structures. Chem. Rev. 2003, 103, 3899-4031. [CrossRef] 
43. Chen, Z.J.; Wang, L.M.; Zou, G.; Tang, J.; Cai, X.F.; Teng, M.S.; Chen, L. Highly selective fluorescence turn-on chemosensor based on naphthalimide derivatives for detection of copper(II) ions. Spectrochim. Acta Part A 2013, 105, 57-61. [CrossRef]

44. Duke, R.M.; Veale, E.B.; Pfeffer, F.M.; Kruger, P.E.; Gunnlaugsson, T. Colorimetric and fluorescent anion sensors: An overview of recent developments in the use of 1,8-naphthalimide-based chemosensors. Chem. Soc. Rev. 2010, 39, 3936-3953. [CrossRef]

45. Parthiban, C.; Ciattini, S.; Ciattinia, L.; Elango, K.P. Colorimetric sensing of anions by Cu(II), $\mathrm{Co}(\mathrm{II}), \mathrm{Ni}(\mathrm{II})$ and $\mathrm{Zn}(\mathrm{II})$ complexes of naphthoquinone-imidazole hybrid-Influence of complex formation on selectivity and sensing medium. Sens. Actuators B Chem. 2016, 231, 768-778. [CrossRef]

46. Escudero, D. Revising intramolecular photoinduced electron transfer (PET) from first-principles. Acc. Chem. Res. 2016, 49, 1816-1824. [CrossRef]

47. Inoue, K.; Aikawa, S.; Sakamaki, M.; Sakamaki, Y. Colorimetric $\mathrm{Co}^{2+}$ sensor based on an anionic pyridylazo dye and a cationic polyelectrolyte in aqueous solution. Polym. Int. 2018, 67, 1589-1594. [CrossRef]

48. Lim, N.C.; Shuster, J.V.; Porto, M.C.; Tanudra, M.A.; Yao, L.; Freake, H.C.; Brückner, C. Coumarin-based chemosensors for Zinc(II): Toward the determination of the design algorithm for CHEF-type and ratiometric probes. Inorg. Chem. 2005, 45, 2018-2030. [CrossRef]

49. Gorse, A.D.; Pesquer, M. Intramolecular charge transfer excited state relaxation processes in para-substituted N,N-Dimethylaniline: A theoretical study including solvent effects. J. Phys. Chem. 1995, 99, 4039-4049. [CrossRef]

50. Balzani, V. (Ed.) Electron Transfer in Chemistry; Wiley-VCH: Weinheim, Germany, 2001.

51. Natali, M.; Campagna, S.; Scandola, F. Photoinduced Electron Transfer across Molecular Bridges: Electronand Hole-Transfer Superexchange Pathways. Chem. Soc. Rev. 2014, 43, 4005-4018. [CrossRef]

52. Daly, B.; Ling, J.; de Silva, A.P. Current Developments in Fluorescent PET (Photoinduced Electron Transfer) Sensors and Switches. Chem. Soc. Rev. 2015, 44, 4203-4211. [CrossRef]

53. Stennett, E.M.S.; Ciuba, M.A.; Levitus, M. Photophysical Processes in Single Molecule Organic Fluorescent Probes. Chem. Soc. Rev. 2014, 43, 1057-1075. [CrossRef]

54. Sinha, S.; Mukherjee, T.; Mathew, J.; Mukhopadhyay, S.K.; Ghosh, S. Triazole-based $\mathrm{Zn}^{2+}$-specific molecular marker for fluorescence bioimaging. Anal. Chim. Acta 2014, 822, 60-68. [CrossRef]

55. Nagarkar, S.S.; Joarder, B.; Chaudhari, A.K.; Mukherje, S.; Ghosh, S.K. Highly selective detection of nitro explosives by a luminescent metal-organic framework. Angew. Chem. Int. Ed. 2013, 52, 2881-2885. [CrossRef]

56. Fu, Y.; Li, P.; Kang, J.X.; Liu, X.Y.; Li, G.Y.; Ye, F. A novel 1,8-naphthalimide derivative as an efficient silver(I) fluorescent sensor. J. Lumin. 2016, 178, 156-162. [CrossRef]

57. Xu, L.; Xu, Y.F.; Zhu, W.P.; Yang, C.M.; Han, L.; Qian, X.H. A highly selective and sensitive fluorescence "turn-on" probe for $\mathrm{Ag}^{+}$in aqueous solution and live cells. Dalton Trans. 2012, 41, 7212-7217. [CrossRef]

Sample Availability: Samples of the compounds are not available from the authors.

(C) 2019 by the authors. Licensee MDPI, Basel, Switzerland. This article is an open access article distributed under the terms and conditions of the Creative Commons Attribution (CC BY) license (http://creativecommons.org/licenses/by/4.0/). 